\title{
The Importance of Revitalizing Sentani Traditional Proverbs
}

\author{
Wigati Yektiningtyas, Aleda Mawene \\ Universitas Cenderawasih \\ wigati_y@yahoo.com
}

\begin{abstract}
Sentani is one of hundred tribes in Papua that is rich with folklore. One of them is traditional proverb that used to be passed down from one generation to another generation. Proverb brought invaluable virtues that were used by the old Sentani people to teach about social life, wisdom, norms, ethics, ettiquette, and aesthetics. Unfortunately, traditional proverb is not recognized anymore by most of Sentani people, especially the young generation. They even see it as something "old fashioned". The research aimed at revitalizing those expression by using itin some social practices. The data of proverbs were collected from informants in Eastern, Central, and Western Sentani byclose observation, interviews, recordings, transcription, translation and focus group discussions (FGD) with the tribal chiefs, elderly people, and young generation. The research adopted socio-cultural and ethnolinguistic approaches. From the research, it revealed that Sentani traditional proverb should be preserved to avoid its extinction and revitalized by active uses in daily life practices, i.e. (1) formal/nonformal education and (2) public education.
\end{abstract}

Keywords: Sentani proverb; preservation; revitalization

\section{INTRODUCTION}

Sentani people who live in the edges of Lake Sentani and in islands in the lake is rich with folklore, i.e. folktale, oral poem, proverb, folksong, dance, traditional architecture, etc. Ironically most people of Sentani do not recognize their own cultural heritages.Emphirical experiences and researches done in 2011-2018 showed that only limited tribal chiefs and some elderly people who recognize still them. One of heritages that is almost extinct is traditional proverb, that is words of wisdom that was used as social guidance. Agustina Modouw (female social leader/66 years) and Ramses Ohee (ondofolo/tribal chief of Waena, 83 years) said that in the past the roles of proverbs were very important: teaching people about social life, wisdom, norms, ethics, ettiquette, and aesthetics. Old Sentani people did not only know or recited the words of wisdom but the really lived by them. For instance, since Sentani people were not "direct people" they prefer to use "indirect language" to teach others (J. Modouw, 56 years) . To criticize a lazy person who ate much, a proverb said "hamang nenaeisele emei roibuyae helemende" (food does not come automatically, except by working hard) was used. To remind people about the significance of honesty, Sentani people said "hu jokho erele" (the sun is watching). Hu means "the sun", but it also refers to "gods". Since they were watched by gods, they were afraid to commit bad deeds. With those words either as a criticism or reminder, no one was angry or insulted since they all knew those words of wisdom as their principle of life. Another example, Sentani people idealized peaceful and prosperous places. It was reflected in one of their proverbs that said, "Igwa yo hubayo, Igwa yo manjo; Raei jo hubayo, Raei jo manjo" (Igwa, a prosperous and peaceful village, Igwa, a village with good tradition; Raei, a prosperous and peaceful village, Raei, a village with good tradition). To live this philosophy, everybody had to be aware and tried hard to make their villages peaceful, prosperous, and had good tradition. Working hard, respecting others, cooperation, and communication were the keys. Seeing the values the proverb brings with, it is important to preserve it to be acknowledged and appreciated, especially by young generation of Sentani.

The research considers to find ways out to preserve Sentani traditional proverbs. From the observation, interview, and Focus Group Discussion with the informants, it is worthy to note that different generationshad their own ideas and needs in utilizing traditional proverbs. Some young informants like RM, (12 years), (IO, 15 years), (NO, 14 years) wanted to learn proverb at school so they can earn the language at once. Besides, they also hoped to have it more modern, up to date, and fresh that represented their life. They were happy reading a proverb that said "melire meugere ereijae" (do not turn your head to the right and to the left). This proverb means that someone needs to be persistent and consistent in doing something, not easily to be distracted. They said that the proverb was insightful and reminded them to be serious in persuing their dream by learning and working hard. A house wife (KM, 57 years) wanted to be "reminded" by the proverb and some tribal chiefs (RO, 83 years and MK, 70 years) wanted to relearn traditional proverb to enrich their speech and teachings.

There are two main questions of the research, namely (1) why is it important to revitalize Sentani traditional proverb? (2) how to revitalize Sentani traditional proverbs?. The research aims at answering the research questions, i.e. (1) discussing why it is important to revitalize Sentani traditional proverbs, and (2) exploring various ways in revitalizing Sentani traditional proverb. This research hopefully gives input to somestakeholders in Jayapura Regency, especially Department of Education and Culture in adopting or infusing Sentani traditional proverb in teaching learning materials and Department of Industry in supporting creative economy. 


\title{
II. METHODS
}

This research was a qualitative one that adopts socio-cultural and ethnolinguistic approaches. As a social product, Sentani proverb could not be separated form Sentani socio-cultural background (Dundes, 1980; Abrams, 1979) hus in analyzing it, it needed to relate it to Sentani people's life, i.e. socio-culture, philosophy, and mythology. Data of proverbs were collected in Eastern Sentani (Waena Kampung and Asei Island), Central Sentani (Ifale and Yahim), and Western Sentani (Doyo Baru and Kwaderware) in 2014-2017 from the informants: tribal chiefs (ondofolo/khote) and elderly people.A three year research was needed due to the difficulties of having the representative informants. Techniques of observation, interviews, and recordings were used. After gaining the data, transcription, translation, verification were done. Focus Group Discussion with informants and local governments was hold to recheck the proverbs' translation and their opinion about the existence, function and revitalization of Sentani traditional proverb. Three dialects of Sentani language (eastern, central, and western dialects) were not taken into account since dialects did not influence the meaning of the proverbs.

\section{Why Revitalizing Sentani Traditional Proverbs?}

\section{FINDING AND DISCUSSION}

Sentani traditional proverb is important to be revitalized because of it is valuable sources of socio-cultural values and media of character building for young generation. As one socio-cultural heritages, Sentani traditional proverb in the past played important roles in teaching people about social life, wisdom, norms, ethics, ettiquette, and aesthetics. Nowadays, those values were ignored by Sentani people and especially by young generation since they do not recognize the proverb anymore. This section explores the proverb that can be used as sources for young generation to learn about their ancestors' socio-cultual values.

Sentani people are known for their strict social life. One of the proverbs said:

\author{
"Igwayo hubayo, hubayo manjo \\ Raeijo hubayo, Raeijo manjo” \\ (Igwa, a prosperous village, a village withgood tradition \\ Raei, a prosperous village, a village withgood tradition)
}

This proverb portrays Sentani people's idealization of harmonious social life. Sentani people prioritized prosperity physically and spiritually. To realize this, people had to keep the balance of the right and obligation. Coorperation, mutual respect, mutual understanding, and communication are needed. For Sentani people, helping others is the spirit of life. Individualism was avoided. Another proverb expressed "holona kuku mehali yona royau aka paeke" (in the forest $k u k u$ and mehali trees live side by side). Kuku and mehali are Sentani traditional names of trees that grow side by side in the forest. This expression depicts that like those trees in the forest that can grow together, people have to live together harmoniously. Harmony for Sentani people is important. Harmony may only be achieved if there is a balance of three relations, i.e. relation between people and god, people and people, and people and nature. One is not allowed to destroy another one.

Proverb also reflects Sentani people's local wisdom that was used as source of life guidance. A proverb says "hu joko erele" (the sun is watching). Literally, $h u$ means the sun but in the past $h u$ also refers to god and now it refers to God. This expression underlines about the importance of honesty. People were taught to be honest in life. People were blessed (onomi) if they were honest and they were cursed if they were not honest. Honesty resulted in prosperity, health, and happiness while falsehood resulted in poverty, sickness and death. For Sentani people "hu waisaeketei, nauka menggeten" (the sun does not rise from the west). This means that truth cannot be hidden. A proverb advises "ofae bline hu heh eyarole" (an open leaf will get more sunshine). This expression suggests that the more people give the more they willbe blessed. For Sentani people helping, loving, and respecting others are important. They were taught to treat others as their own brothers/sisters/relatives to be blessed and led a prosperous and happy life. It is said "akahi paekehi yae ewelende, wali onomi honomi eungekende" (if you treat others as your relatives, your life will be proposperous and peaceful). To be discipline and persistent are important. It is revealed "melire meugere ereijae" (do not turn your head to the right and to the left). It is important to be persistent in doing things, not to be easily distracted.

Norms are prioritized as social guidance to be followed. A tribal chief (ondofolo) has a responsibility to take care of poor people, widows, and girls. It is said in one of the proverbs "oboyoku miyae nale maengge fa naeijae yeleikoi" (poor people, widows an girls are his responsibility). Women has to be productive. She has to provide food for her family. It is highlighted in a proverb "ebe puenende" (a woman with a pot full of food). Unproductive woman is denied in the community. This kind of woman is pictured as "ebe ere felensande" (woman withupside down pot). Family with girls and pigs is ideal. Girls are "media" to have bride price (robhoni) and pigs are "food" to be exchanged with bride price as it is said in "maengge imaena nekele, obo kelenakole" (girls in the house, pigs in underneath of the house). 
Sentani people adored work ethics. Wakhe (hard work) is the spirit of their life. Some proverbs say "aye manu balate yahim yam aurawale" (the bird sings, morning breaks) and "hamang nenaeisele emeiroi buyae helemende" (food does not come by itself, it must be afforded). Those proverbs remind that in the morning people have to get up early in the morning to start working. For them food does not automatically come, food has to be afforded. People have to be serious in working to provide food as it is expressed in a proverb "heke a riyae-riyae maye-maye" (to work in the garden enthusiastically). Only by working hard, people can eat and live. Yambi (lazy people) are avoided in life.

Ettiquette is high valued in Sentani. Respecting elder people is a must. It is said in proverbs "afanei abunei ana-punae naefabende, kena u foi fae efraubonde" (when your uncle and aunt give advice, you have to listen to them) and "heu foi kha foi eukende nawaka along bere eumikelende" (if you got good fish, you have to give it to your older brothers or your father's older brothers). Young people are not allowed to argue with older people. They have to listen to them by respecting them and giving them best food and service.

Sentani people like arts. They do not only pour it in their paintings and carvings but also express it in the way they talk. They have to select good words before talking. It is said "wa urafaeu kawau mekai waekaita eranaite a kolonaete" (you will be respected from the way you talk and do). Sentani people do not like rude people. Even they use some metaphor to describe something. For example they use "obo yokhu" (pig and dog) that refers to low class people. Beauty, tidiness, and cleanliness are valued by people. "nauma welauma momokaugake" (the hair is neat) is an expression to complement beautiful and clean girl. An informant said, that a beautiful and clean girl is a sign that she is a candidate of good mother who is capable to take care of her family in the future.

Seeing the values that Sentani traditional proverb bring with, those values can be used as media of character building. Nowadays, Sentani young generation show different character from their ancestors. From the observation and information from the informants, young generation of Sentani tend to be indiscipline, unproductive, dependent, ignorant, individualistic, and do not like process. Some proverbs can be used to motivate them to be hardworking, diligent, discipline and productive. Witout those character, young generation of Sentani cannot compete with others. They will be left behind since the world move faster and competitive.

\section{Utilization of Sentani Proverbs in Modern Era}

In modern era, revitalizing Sentani traditional proverbis challenging. Since it is seen "old fashioned" by young generation, this writing put forward ideas to "repack" it in a fresher and modern way by infusing it in education, namely (a)formal/nonformal education and (b) public education.

\section{(a) Formal/nonformal Education}

Sentani language is labelled a "endangered" language. It means that this language will be extinct soon without preservation due to the fact that not many people can speak the language, especially those who live in town. Silzer (1991) found that the native speakers of Sentani language was 25.000. A research in 2016-2018 found that only people in remote islands can speak the language actively while the children use it passively (Yektiningtyas-Modouw dan Monika Gultom, 2018). Various initiatives are needed to encourage the young generation to learn their local language. Interesting and challenging materials are needed to motivate them to learn the language.

One of alternative materials that can be infused in teaching the language is traditional proverb. Since it is composed in short sentences or clauses, proverb isrelatively easier to be used to teach vocabulary, pronunciation, and sentence structure. Besides, infusing proverbs in teaching language is also an effort to encourage socio-cultural awareness of the students from the beginning. This article prioritizes to revitalize Sentani traditional proverb formally by teaching it in SD (Elementary School). Sanusi (2015:212), Mulyana (2004: 177) and Kutha Ratna (2014: 303) highlighted the importance of socio-cultural awareness to be given at school, especially at early childhood education and elementary school by integrating it in some suitable topics of various subjects. This is wise to teach the students about moral, social sensibility, and ettiquette. They are taught to have practical behaviour like praying, making their bed, respecting parents and others, and being honest. A proverb said "hu joko erele" (the sun is watching) reminds them to always follow the rules. Other proverbs like "oro hebayae fenaesi be' (watch when you walk, do not get fall) and melire meugere ereijae" (do not turn your head to the right and to the left) teach the students to be careful and persistent in life.Involving culture in language teaching is also challenging since there are "emotional ties" between the learners and the subject that attract their attention and motivation (Lazar, 2002).

Understanding Sentani socio-culture from the beginning referring to the contextual principle of Curriculum 2013.This context's goal is teaching the students to know about their culture, love their natural and social environment in a global perspective and proud to be the nation inheritance (Kemendikbud, 2016). Referring to the thematic learning in Elmentary School, the value penetration of Sentani proverb can be done in some subjects, i.e. Indonesian language, mathmatics, civics, and sport and health.

For Indonesian subject, for instance, the Core and Basic Competencesof syllabus of Elementary School Grade I enable proverb to be taught. Sustancially,Sentani proverb is a register or figurative language. To utilize proverb as media of effective learning, due to the literacy limitation of grade I, it should be swicthed as a simple slogan in the form 
of label text.Label text is usually used as a transition media of learning verbal to writen language (Mahsun, 2014). For example, the students learn about the word ofae (leaf). The teacher may show a picture of leaf visually and write "ofae" on the picture. Then teacher ask the students to pronounce the word "ofae" correctly.

Beyond the language learning, students are also introduced with the values of a proverb. For example, in " $h u$ jokho erele" (the sun is watching), the students are taught about honesty. This proverb can be infused under the topic of "My Activity" (Syllabus of Grade I, theme 3) and "Activity in the Morning (subtheme 1). The penetrationdone after the teacher helps the students read the material provided in the Student Book which they can find a sentence "the sun shines brightly". The teaher helps the students to tell about their activities in the morning as a braistormig. The teacher may ask them to sing a certain song related to activities in the morning, i.e. "The Sun is Shining Brightly", or "Getting up in the Morning". The teacher then lets the students to choose good and bad activities and underlines that all deeds are wactched (by God). Then the teacher gives an example of a Sentani proverb Sentani "hu jokho erele" (the is sun watching).

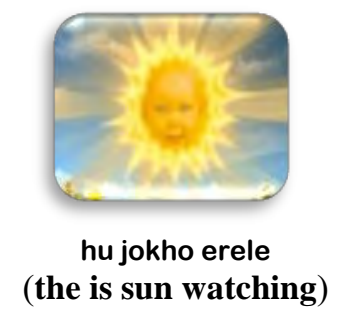

The sentence of the Sentani proverb do not need to be changed but the translation in Indonesian can be simplified as "matahari melihat" (the sun watches). This enables the students to remember it easily. The teacher can help the students in doing reading and writing activities using the method of SAS (Structure-Analisis-Synthesis) as follows.

matahari melihat

hu jokho erele

ma-ta-ha-ri me-li-hat

hu jo-kho e-re-le

$m-a-t-a-h-a-r-i \quad m-e-l-i-h-a-t$

$h-u$ j-o-k-h-o e-r-e-l-e

ma-ta-ha-ri me-li-hat

hu jo-kho e-re-le

matahari melihat

hu jokho erele

Since the students are heterogeneously come from various races of Indonesia, infusing Sentani proverb in teaching learning is a medium to introduce it to other students outside of Sentani. This is a cross cultural understanding teaching that maintains the "unity of diversity" in Indonesia.

Nonformally, revitalization of Sentani traditional proverb can be taught in some Centers of Social Activities like Sentani Customary School. This school was initiated in 2017 in Hobong, Central Sentani as a result of cultural awareness. It is interesting to note that as social initiative, this school is the only one in Papua that teaches about Sentani culture. Compared to teaching proverbs formally at school, teaching in customary school is relatively easy since the students are homogenous. They are all Sentani children of 7-14 years old. Their language levels are also different. In teaching, they can be grouped based on the level. They can learn the simple proverb that consist of clauses like "obo yokhu" (dog and pig), "a mae mae, a hae hae" (talking something bad about others) for the basic level. Long and complex sentence of proverb are taught for the advanced level like "ko ruwele na no kelena honole (the falling coconut will stay under its tree)and "oboyoku miyae nale maengge fa naeijae yeleikoi (common people, girls, widows are his responsibility). From the proverbs, they can also learn pronunciation, vocabulary, phrases, clauses, sentence structure and counting system. To make the learning more interesting, games and songs can be included.

\section{(b) Public Education}

Involving public education in revitalizing Sentani proverb is introducingit to public. It aims at bringing backthe Sentani cultural symbols to life(Wafom, 2017) to be widely acknowledged by people. In modern era, people especially young generation tend to be practical and up to date. To introduce the proverb that are regarded "old fashioned", strategies are needed. To adopt the so called spirit of millenium, proverb can be infused digitally. Proverbs can be put in T-shirt, bag, and mug. 

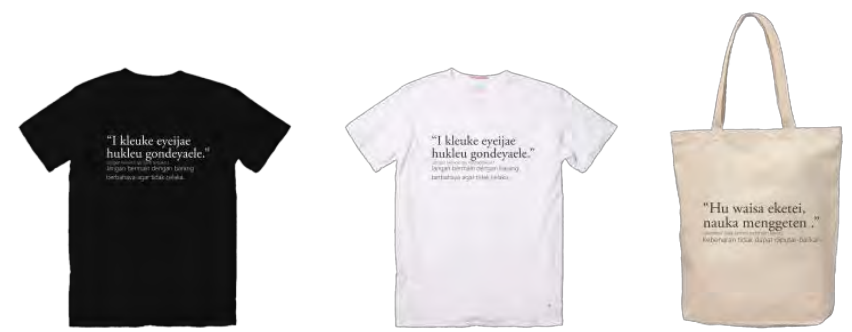

For young generation, those proverbs, "ikleuke eyeijae hukleu gondeyaele” (do not play with fire, you will be burnt) and "hu waisaeketei, nauka menggeten" (the sun does not rise from the west" are like motto or slogan that will remind them be persistent, discipline and honest. From the proverbsthey can learn about the values of truth. Besides, they can also learn Sentani language in modern way. For common people, putting proverb in a mug is another alternative.

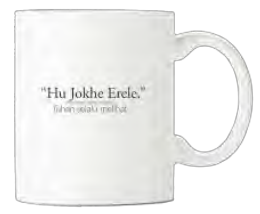

From the mug, people are reminded to be honest and always dogood deeds since they are always "watched" like proverb says "hu jokho erele" (the sun is watching). Besides, proverbs can also be used as motto and slogan that can be put in school, office or road to remind people to do good deeds in life.

By introducing the proverb publicly in more modern way, modern Sentani people are more confident in bringing their identity and introduce it to other people outside their community. This creativity may also encourage creative industry among Sentani people that support them economically.

\section{CONCLUSION}

Sentani traditional proverb is not recognized by most people of Sentani and they are even seen as "old fashioned" by young generation. The proverbs with the socio-cultural values that teach about social life, wisdom, norms, ethics, ettiquette, and aesthetics are too valuable to be extinct. Thus revitalization is important. They are some ways of revitalizing the proverbs strategically in daily practices, namely (a) formally, infusing it in teaching learning process in Grade I of Elementary School, (b) nonformally, teaching it in Center of Social Activities like in Sentani Customary School, (c) publically, introducing it to wider people in modern digital ways. The strategies bring some advantages, i.e. (1) motivating Sentani people to acknowledge and love their heritages, (2) introducing the heritages to other community outside of Sentani people, (3) teaching local language that is almost extinct, (4) supporting creative economy of Sentani people specifically and Jayapura people generally. Active respons from the local government is needed to save the heritages from extinction and to avoid Sentani young generation from losing their roots.

\section{References}

Abrams, M.H. (1979). The Mirror and the Lamp: Romantic Theory and the Critical Tradition. New York: Oxford University Press.

Dundes, Alan. (1980). Interpreting Folklore. Bloomington and London: Indiana University Press.

Lazar, G. (2002). Literature and Language Teaching. Cambridge: Cambridge University Press

Kemendikbud. (2016). Kurikulum 2013. Kompetensi DasarSekolah Dasar/Madrasah Ibtidaiyah. Jakarta: Kemendikbud.

Kutha Ratna, N. (2014). Peranan Karya Sastra, Seni, dan Budaya dalam Pendidikan Karakter. Yogyakarta:Pustaka Pelajar.

Mulyana, R. (2004). Mengartikulasikan Pendidikan Nilai. Bandung:Alfabeta.

Mahsun, M.S. (2014). Teks Dalam Pembelajaran Bahasa Indonesia Kurikulum 2013. Jakarta:PT Raja Grafindo Persada.

Sanusi, A. (2015). Sistem Nilai: Alternatif Wajah-wajah Pendidikan. Bandung:Nuansa Cendekia.

Silzer, P.J., Duane Clouse, \& H Heikkinen. (1991). Index of Irian Jaya Language. Jayapura: Uncen-SIL.

Wafom, Y. (2017). "Implementasi Otonomi Khusus dalam Kebijakan Bahasa Terkait Penggunaan Simbol-simbol Budaya dalam Ruang Publik di Kota Jayapura". (Implementation of Speific Aotonomy in Language Policy Related to the Uses of Cltural Symbols in Public Space in Jayapura Municipality) Jayapura: Universitas Cenderawasih (A Research Report PNBP Uncen). 
Yektiningtyas-Modouw, Wigati \& M. Gultom. (2018) "Pemertahanan Bahasa Sentani untuk Anak melalui Penggunaan Cerita Rakyat di Kabupaten Jayapura, Papua” (Preservation of Sentani Language for Children by Using Folktales in Jayapura Regency, Papua). Jayapura: Universitas Cenderawasih (A Research Report) 